\title{
Hydrologic Modeling of Pathogen Fate and Transport
}

Sarah M. Dorner ${ }^{1}$, William B. Anderson ${ }^{1}$, Robin M. Slawson ${ }^{2}$, Nicholas Kouwen ${ }^{3}$, Peter M. Huck ${ }^{1}$

${ }^{1}$ NSERC Chair in Water Treatment, Department of Civil Engineering, University of Waterloo,

Waterloo, Ontario, Canada, N2L 3G1. ²Department of Biology, Wilfrid Laurier University, Waterloo, Ontario, Canada, N2L 3C5. ${ }^{3}$ Waterloo Hydrology Lab, Department of Civil Engineering University of Waterloo, Waterloo, Ontario, Canada, N2L 3G1

sdorner@tei.umass.edu 


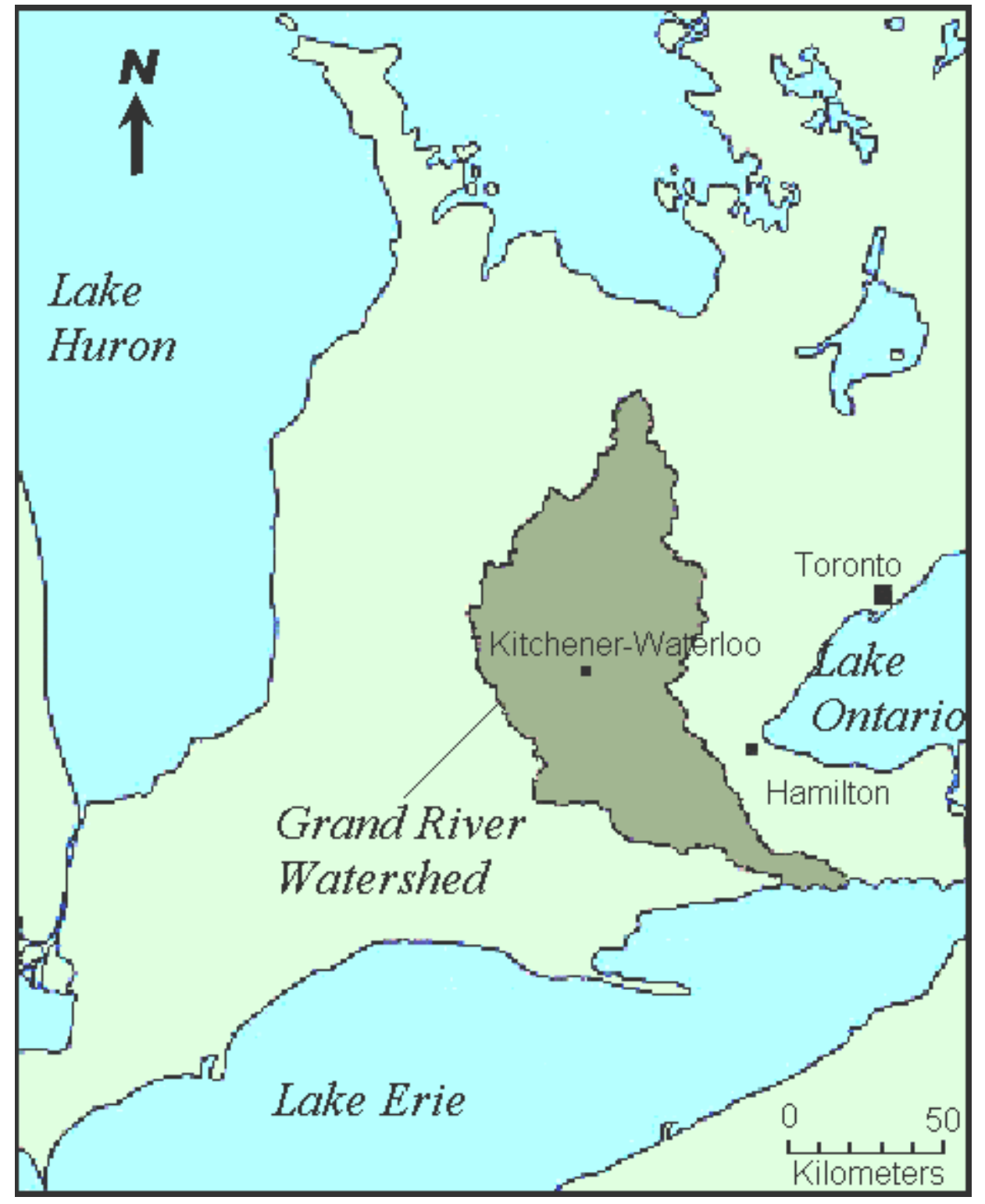

Figure S1. Location of the Grand River Watershed within Southwestern Ontario, Canada

\section{Microbial Inactivation}

Tables S1 to S3 present the calculated first order inactivation constants and the source of the data that were used to identify mean seasonal inactivation values used in the model and presented in Tables 1 to 3. 
Table S1. First Order Inactivation Constants of Select Microorganisms in Manure

\begin{tabular}{|c|c|c|c|}
\hline Microorganism & Source & Temperature $\left({ }^{\circ} \mathrm{C}\right)$ & $K\left(d^{-1}\right)$ \\
\hline Cryptosporidium spp. & Olson et al. (1999) & -4 & 0.0137 \\
\hline Cryptosporidium spp. & Olson et al. (1999) & 4 & 0.0332 \\
\hline Cryptosporidium spp. & Robertson et al. (1992) & 4 & 0.2616 \\
\hline Cryptosporidium spp. & Olson et al. (1999) & 25 & 0.0376 \\
\hline Giardia spp. & Olson et al. (1999) & 4 & 0.0457 \\
\hline Giardia spp. & Olson et al. (1999) & 25 & 0.1850 \\
\hline E. coli $\mathrm{O} 157$ & Himathongkham et al. (1999) & 4 & 0.1100 \\
\hline E. coli $\mathrm{O} 157$ & Himathongkham et al. (1999) & 4 & 0.0540 \\
\hline E. coli $\mathrm{O} 157$ & Himathongkham et al. (1999) & 4 & 0.0460 \\
\hline E. coli $\mathrm{O} 157$ & Himathongkham et al. (1999) & 4 & 0.0260 \\
\hline E. coli $\mathrm{O} 157$ & Kudva et al. (1998) & 4 & 0.6799 \\
\hline E. coli $\mathrm{O} 157$ & Wang et al. (1996) & 5 & 0.1035 \\
\hline E. coli $\mathrm{O} 157$ & Wang et al. (1996) & 5 & 0.1578 \\
\hline E. coli $\mathrm{O} 157$ & Himathongkham et al. (1999) & 20 & 0.0460 \\
\hline E. coli $\mathrm{O} 157$ & Himathongkham et al. (1999) & 20 & 0.0740 \\
\hline E. coli $\mathrm{O} 157$ & Himathongkham et al. (1999) & 20 & 0.0680 \\
\hline E. coli $\mathrm{O} 157$ & Himathongkham et al. (1999) & 20 & 0.1300 \\
\hline E. coli $\mathrm{O} 157$ & Wang et al. (1996) & 22 & 0.1797 \\
\hline E. coli $\mathrm{O} 157$ & Wang et al. (1996) & 22 & 0.2316 \\
\hline E. coli $\mathrm{O} 157$ & Kudva et al. (1998) & 23 & 0.3183 \\
\hline E. coli $\mathrm{O} 157$ & Wang et al. (1996) & 37 & 0.2067 \\
\hline E. coli $\mathrm{O} 157$ & Wang et al. (1996) & 37 & 0.2384 \\
\hline E. coli $\mathrm{O} 157$ & Himathongkham et al. (1999) & 37 & 0.1120 \\
\hline E. coli $\mathrm{O} 157$ & Himathongkham et al. (1999) & 37 & 0.2790 \\
\hline E. coli $\mathrm{O} 157$ & Himathongkham et al. (1999) & 37 & 0.3150 \\
\hline
\end{tabular}


Table S2. First Order Inactivation Constants of Select Microorganisms in Soil and Manure-Amended Soil

\begin{tabular}{|c|c|c|c|}
\hline Microorganism & Source & Temperature ${ }^{\circ} \mathrm{C}$ & $K\left(d^{-1}\right)$ \\
\hline Cryptosporidium spp. & Olson et al. (1999) & -4 & 0.0113 \\
\hline Cryptosporidium spp. & Kato et al. (2004) & 0 & 0.0280 \\
\hline Cryptosporidium spp. & Kato et al. (2004) & 0 & 0.0310 \\
\hline Cryptosporidium spp. & Kato et al. (2004) & 0 & 0.0280 \\
\hline Cryptosporidium spp. & Olson et al. (1999) & 4 & 0.0344 \\
\hline Cryptosporidium spp. & Olson et al. (1999) & 25 & 0.0706 \\
\hline Cryptosporidium spp. & Nasser et al. (2003a) & 25 & 0.0550 \\
\hline Giardia spp. & Olson et al. (1999) & -4 & 0.3289 \\
\hline Giardia spp. & Olson et al. (1999) & 4 & 0.0473 \\
\hline Giardia spp. & Olson et al. (1999) & 25 & 0.1850 \\
\hline Giardia spp. & Nasser et al. (2003a) & 25 & 0.0834 \\
\hline Campylobacter spp. & Hutchison et al. (2004) & 16 & 0.0846 \\
\hline E. coli $\mathrm{O} 157$ & Jiang et al. (2002) & 5 & 0.2008 \\
\hline E. coli $\mathrm{O} 157$ & Jiang et al. (2002) & 5 & 0.1902 \\
\hline E. coli $\mathrm{O} 157$ & Jiang et al. (2002) & 5 & 0.1665 \\
\hline E. coli $\mathrm{O} 157$ & Jiang et al. (2002) & 5 & 0.1650 \\
\hline E. coli $\mathrm{O} 157$ & Fenlon et al. (2000) & 10 & 0.0625 \\
\hline E. coli $\mathrm{O} 157$ & Fenlon et al. (2000) & 10 & 0.0661 \\
\hline E. coli $\mathrm{O} 157$ & Fenlon et al. (2000) & 10 & 0.0644 \\
\hline E. coli $\mathrm{O} 157$ & Jiang et al. (2002) & 15 & 0.0758 \\
\hline
\end{tabular}




\begin{tabular}{llll}
\hline E. coli $\mathrm{O} 157$ & Jiang et al. (2002) & 15 & 0.0666 \\
E. coli $\mathrm{O} 157$ & Jiang et al. (2002) & 15 & 0.0792 \\
E. coli $\mathrm{O} 157$ & Jiang et al. (2002) & 15 & 0.0743 \\
E. coli $\mathrm{O} 157$ & Hutchison et al. (2004) & 16 & 0.0782 \\
E. coli $\mathrm{O} 157$ & Jiang et al. $(2002)$ & 21 & 0.0447 \\
E. coli $\mathrm{O} 157$ & Jiang et al. (2002) & 21 & 0.0460 \\
E. coli $\mathrm{O} 157$ & Jiang et al. (2002) & 21 & 0.0529 \\
E. coli $\mathrm{O} 157$ & Jiang et al. (2002) & 21 & 0.0418 \\
\hline
\end{tabular}

Table S3. First Order Inactivation Constants of Select Microorganisms in Water

\begin{tabular}{|c|c|c|c|}
\hline Microorganism & Source & Temperature ${ }^{\circ} \mathrm{C}$ & $K\left(d^{-1}\right)$ \\
\hline Cryptosporidium spp. & Olson et al. (1999) & -4 & 0.0106 \\
\hline Cryptosporidium spp. & Sattar et al. (1999) & 4 & 0.0105 \\
\hline Cryptosporidium spp. & Sattar et al. (1999) & 4 & 0.0170 \\
\hline Cryptosporidium spp. & Olson et al. (1999) & 4 & 0.0061 \\
\hline Cryptosporidium spp. & Pokorny et al. (2002) & 4 & 0.0210 \\
\hline Cryptosporidium spp. & Robertson et al. (1992) & 4 & 0.4664 \\
\hline Cryptosporidium spp. & Pokorny et al. (2002) & 10 & 0.0086 \\
\hline Cryptosporidium spp. & Nasser et al. (2003b) & 15 & 0.0017 \\
\hline Cryptosporidium spp. & Sattar et al. (1999) & 20 & 0.0712 \\
\hline Cryptosporidium spp. & Sattar et al. (1999) & 20 & 0.0569 \\
\hline Cryptosporidium spp. & Sattar et al. (1999) & 20 & 0.0541 \\
\hline Cryptosporidium spp. & Sattar et al. (1999) & 20 & 0.0483 \\
\hline Cryptosporidium spp. & Pokorny et al. (2002) & 22 & 0.0833 \\
\hline Cryptosporidium spp. & Olson et al. (1999) & 25 & 0.0320 \\
\hline Cryptosporidium spp. & Sattar et al. (1999) & 30 & 0.0976 \\
\hline Cryptosporidium spp. & Sattar et al. (1999) & 30 & 0.1395 \\
\hline Cryptosporidium spp. & Nasser et al. (2003b) & 30 & 0.0029 \\
\hline
\end{tabular}


$\begin{array}{llll}\text { Giardia } \text { spp. } & \text { Olson } \text { et al. }(1999) & 4 & 0.0221 \\ \text { Giardia } \text { spp. } & \text { Olson } \text { et al. }(1999) & 25 & 0.1026\end{array}$

Campylobacter spp. $\quad$ Kohornen and Martikainen (1991a) $4 \quad 1.1520$

$\begin{array}{lll}\text { Campylobacter spp. } & \text { Kohornen and Martikainen (1991a) } \quad 4 & 1.4430\end{array}$

$\begin{array}{llll}\text { Campylobacter spp. } & \text { Thomas et al. (1999) } & 5 & 0.0200\end{array}$

$\begin{array}{llll}\text { Campylobacter spp. } & \text { Thomas et al. (1999) } & 5 & 0.0600\end{array}$

$\begin{array}{llll}\text { Campylobacter spp. } & \text { Thomas et al. (1999) } & 5 & 0.0500\end{array}$

$\begin{array}{llll}\text { Campylobacter spp. } & \text { Thomas et al. (1999) } & 5 & 0.0500\end{array}$

$\begin{array}{llll}\text { Campylobacter spp. } & \text { Chynoweth } \text { et al. (1998) } & 5 & 0.0672\end{array}$

$\begin{array}{llll}\text { Campylobacter spp. } & \text { Chynoweth } \text { et al. (1998) } & 5 & 0.1224\end{array}$

$\begin{array}{llrr}\text { Campylobacter spp. } & \text { Thomas et al. (1999) } & 15 & 0.1200\end{array}$

$\begin{array}{llll}\text { Campylobacter spp. } & \text { Thomas et al. (1999) } & 15 & 0.1300\end{array}$

$\begin{array}{llll}\text { Campylobacter spp. } & \text { Thomas et al. (1999) } & 15 & 0.1100\end{array}$

$\begin{array}{llll}\text { Campylobacter spp. } & \text { Thomas et al. (1999) } & 15 & 0.1500\end{array}$

$\begin{array}{llll}\text { Campylobacter spp. } & \text { Kohornen and Martikainen (1991a) } & 20 & 20789\end{array}$

$\begin{array}{llll}\text { Campylobacter spp. } & \text { Kohornen and Martikainen (1991a) } \quad 20 & 3.5460\end{array}$

$\begin{array}{llll}\text { Campylobacter spp. } & \text { Thomas et al. (1999) } & 25 & 1.2800\end{array}$

$\begin{array}{llll}\text { Campylobacter spp. } & \text { Thomas et al. (1999) } & 25 & 1.5000\end{array}$

$\begin{array}{llr}\text { Campylobacter spp. } & \text { Thomas } \text { et al. (1999) } & 25\end{array}$

$\begin{array}{llrr}\text { Campylobacter spp. } & \text { Thomas et al. (1999) } & 25 & 1.6200\end{array}$

$\begin{array}{llll}\text { Campylobacter spp. } & \text { Thomas et al. (1999) } & 37.4100\end{array}$

$\begin{array}{llll}\text { Campylobacter spp. } & \text { Thomas et al. (1999) } & 37.7300\end{array}$

$\begin{array}{llll}\text { Campylobacter spp. } & \text { Thomas et al. (1999) } & 37.7500\end{array}$

$\begin{array}{llll}\text { Campylobacter spp. } & \text { Thomas et al. (1999) } & 37.4300\end{array}$
E. coli
Perrot et al. (2003)
4
0.2361
E. coli
Perrot et al. (2003)
4
0.2890 


\begin{tabular}{|c|c|c|c|}
\hline E. coli & Terzieva and McFeters (1991) & 6 & 0.6597 \\
\hline E. coli & Terzieva and McFeters (1991) & 6 & 0.7733 \\
\hline E. coli & Terzieva and McFeters (1991) & 6 & 0.2388 \\
\hline E. coli & Sinton et al. (2002) & 14 & 0.4104 \\
\hline E. coli & Sinton et al. (2002) & 14 & 0.5520 \\
\hline E. coli & Nasser et al. (2003b) & 15 & 0.1361 \\
\hline E. coli & Terzieva and McFeters (1991) & 16 & 0.8888 \\
\hline E. coli & Terzieva and McFeters (1991) & 16 & 1.1900 \\
\hline E. coli & Terzieva and McFeters (1991) & 16 & 0.8394 \\
\hline E. coli & Perrot et al. (2003) & 18 & 0.2310 \\
\hline E. coli & Perrot et al. (2003) & 18 & 0.3310 \\
\hline E. coli & Banning et al. (2002) & 28 & 0.8330 \\
\hline E. coli & Banning et al. (2002) & 28 & 0.7548 \\
\hline E. coli & Banning et al. (2002) & 28 & 0.1736 \\
\hline E. coli & Banning et al. (2002) & 28 & 0.3839 \\
\hline E. coli & Banning et al. (2002) & 28 & 0.3839 \\
\hline E. coli & Banning et al. (2002) & 28 & 0.3714 \\
\hline E. coli & Nasser et al. (2003b) & 30 & 0.1429 \\
\hline
\end{tabular}

\section{Loading to the Soil surface and Inactivation}

Assuming that the initial mass of pathogens in storage is zero, the numbers of pathogens on a daily basis can be modeled as:

$$
M(t)=\frac{W}{k}\left(1-e^{-k t}\right)
$$


Where:

$\mathrm{M}(\mathrm{t})$ is the number of pathogenic microorganisms in the manure storage facility [\#],

$\mathrm{W}$ is the daily pathogen loading to manure storage, from PPLM results [\#/day],

$\mathrm{k}$ is the inactivation of pathogens in manure [1/day],

$\mathrm{t}$ is time [day].

This section describes the calculations performed to estimate the concentration at the soil surface.

To estimate a concentration at the soil surface, initial mixing of pathogen loading to the top $1 \mathrm{~cm}$ of the soil was assumed:

$$
C_{P_{t h \_s u r}}=P t h_{\text {sur }} \cdot \frac{1 \times 10^{-8}}{p o r}
$$

where

$\mathrm{C}_{\text {Pth_sur }}$ is the concentration of the pathogen in the top $\mathrm{cm}$ of the soil $\left[\# / \mathrm{cm}^{3}\right]$,

$\mathrm{Pth}_{\text {sur }}$ is the pathogen loading [\#/ha],

por is the porosity of the soil, assumed to be independent of soil moisture content [ - ], and $1 \times 10^{-8}$ is a conversion factor from ha to $\mathrm{cm}^{2}$.

The concentration change resulting from the effect of tillage is calculated by:

$$
C_{P_{t h h_{-} s u r_{-} t}}=C_{P_{t h_{-} s u r}} \cdot\left(\frac{\frac{I n_{\text {eff }}}{100}}{\frac{I n_{d e p}}{0.39}}\right)
$$


where

$\mathrm{C}_{\text {Pth_sur_t }}$ is the pathogen concentration incorporated into the soil following tillage $\left[\# / \mathrm{cm}^{3}\right]$

$\mathrm{In}_{\mathrm{eff}}$ is the incorporation efficiency [\%]

$\mathrm{In}_{\mathrm{dep}}$ is the depth of tillage [inches]

0.39 is a conversion factor from inches to centimeters.

\section{Overland Transport - The Hartley Model}

The rainfall energy rate is calculated by (Hartley, 1987):

$E_{r f}=i(11.9+8.7 \log i)$

where

$\mathrm{E}_{\mathrm{rf}}$ is the rainfall energy $\left[\mathrm{J} / \mathrm{m}^{2} / \mathrm{h}\right]$

$\mathrm{i}$ is the rainfall intensity $[\mathrm{mm} / \mathrm{h}]$

The equation for rainfall energy is an empirical relationship adapted from the USLE (39). Although it is empirical, rainfall energy would be the same regardless of whether it is detaching soil particles or pathogens from the soil surface. Precipitation values used in WATFLOOD/SPL were converted to intensity by dividing by the time step and were used to estimate the rainfall energy.

The rate of pathogen detachment as a result of rainfall energy is calculated by:

$$
G_{r f}=E_{r f}(1-G C) \cdot C F \cdot D
$$


where

$G_{\mathrm{rf}}$ is the rate of detachment of pathogenic microorganisms from the soil surface $\left[\# / \mathrm{m}^{2} / \mathrm{h}\right]$,

$\mathrm{CF}$ is the canopy factor based on the percentage of canopy cover of the soil [-],

$\mathrm{D}$ is the "pathogen erodibility" factor, analogous to the soil erodibility factor, determined by calibration $[\# / J]$, and

GC is the ground cover percentage [-].

The energy from runoff that can entrain pathogens is estimated as:

$$
E_{r o}=\left(\frac{60}{K_{f}}\right) \gamma \frac{Q_{L}}{2} S_{o}
$$

where

$\mathrm{E}_{\mathrm{ro}}$ is the rate of energy input to the soil by flow $\left[\mathrm{J} / \mathrm{m}^{2} / \mathrm{h}\right]$,

$\mathrm{Q}_{\mathrm{L}}$ is the unit flow discharge from hydrology section of SPL $\left[\mathrm{m}^{2} / \mathrm{h}\right]$,

$\mathrm{K}_{\mathrm{f}}$ is the overland friction parameter [-],

$\gamma$ is the specific weight of water $\left[\mathrm{kg} \mathrm{m}^{-2} \mathrm{~s}^{-2}\right]$, and

$\mathrm{S}_{\mathrm{o}}$ is the slope $[-]$.

Equation 6 is partly process-based, and partly empirical. The overland friction parameter, $\mathrm{K}_{\mathrm{f}}$, is empirical, and is related to the ground cover density.

The rate of pathogen entrainment from overland flow is calculated as:

$$
G_{r o}=E_{r o} D
$$


where

$\mathrm{G}_{\mathrm{ro}}$ is the runoff pathogen detachment $\left[\# / \mathrm{m}^{2} / \mathrm{h}\right]$

As pathogens are always assumed to be in limited supply, the transport capacity of the flow is not considered to be a factor as the transport capacity is assumed to be unlimited relative to the numbers of microorganisms that may be present. Instead, a check is performed to ensure that the numbers of pathogens that may potentially be transported do not exceed the supply.

The pathogen yield from a given land surface area (e.g. a $1 \mathrm{~km} \times 1 \mathrm{~km}$ grid cell) for an increment of time is estimated as:

$$
Y_{P}=\left(G_{r f}+G_{r o}\right) \cdot \Delta t
$$

$Y_{p}=$ the pathogen yield for the time increment for the basin element and land class that will be routed downstream $\left[\# / \mathrm{m}^{2}\right]$, and

$\Delta \mathrm{t}=$ the time step used in the simulation (1 hour).

Figures S2 and S3 show estimated versus observed E. coli concentrations for June 2002- May 2003 and June 2003- May 2004, respectively. In general, E. coli concentrations were underestimated with the exception of spring 2004. The overestimation of pathogens and indicators for the spring of 2004 can be seen as a consistent "banding" at the top of Figure S3. At times the model predicted no E. coli concentrations, when E. coli was observed, (i.e. values along the x-axis of Figures S2 and S3). 


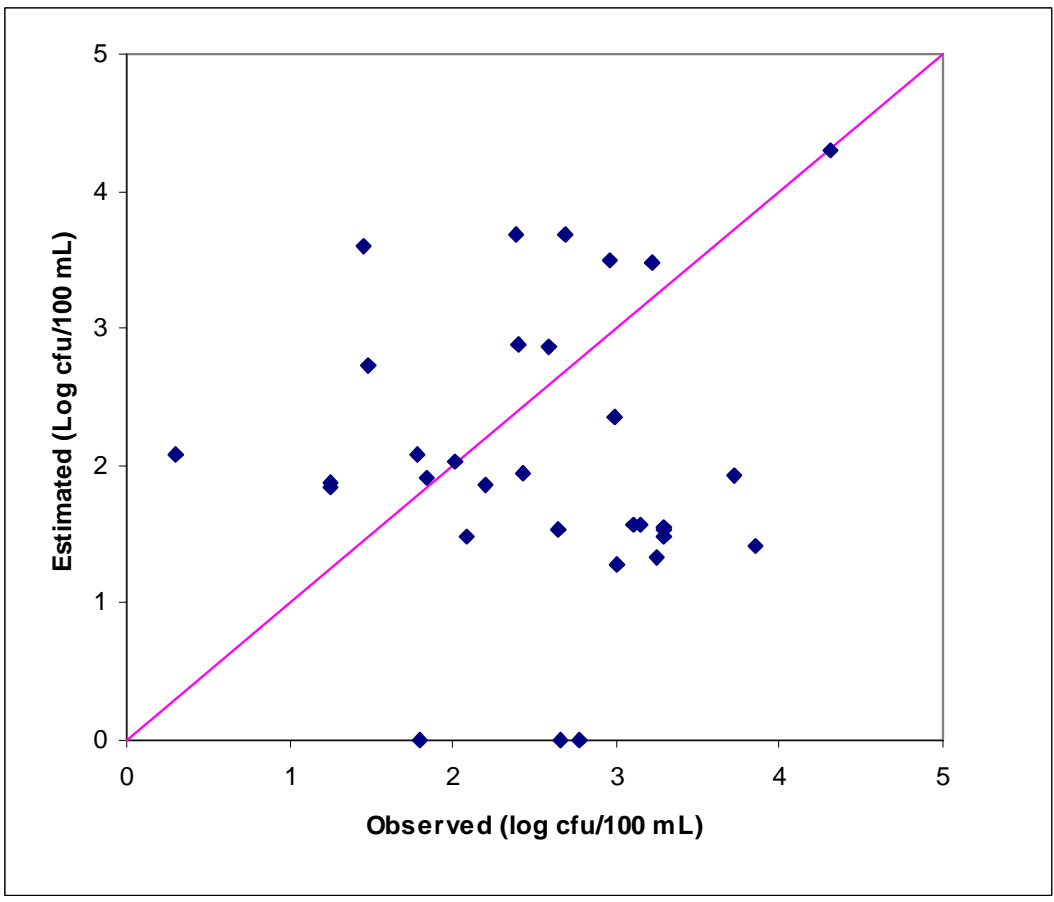

Figure S2. Observed versus estimated $E$. coli densities for June 2002 to May 2003 below Elmira. Spearman rank correlations are significant $(p<0.05)$ for summer and fall 2002.

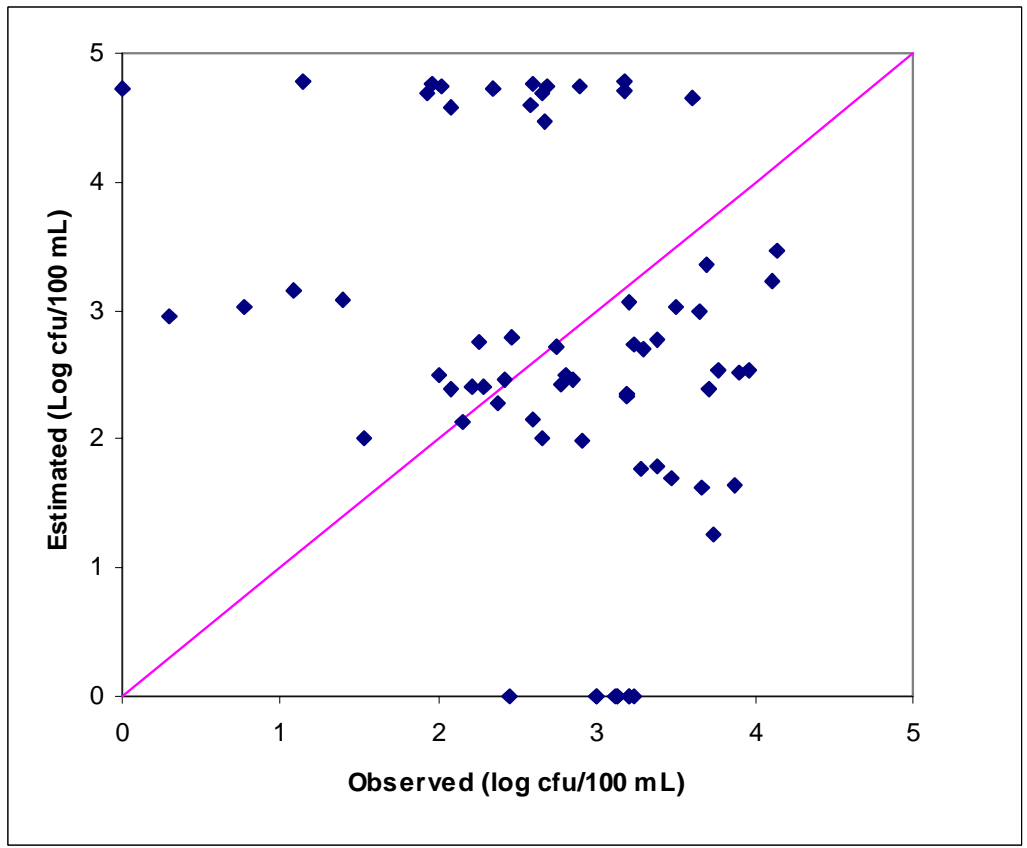


Figure S3. Observed versus estimated $E$. coli densities for June 2003 to May 2004 below EImira. Spearman rank correlations are significant $(p<0.05)$ for summer 2003 , fall 2003 , and spring 2004.

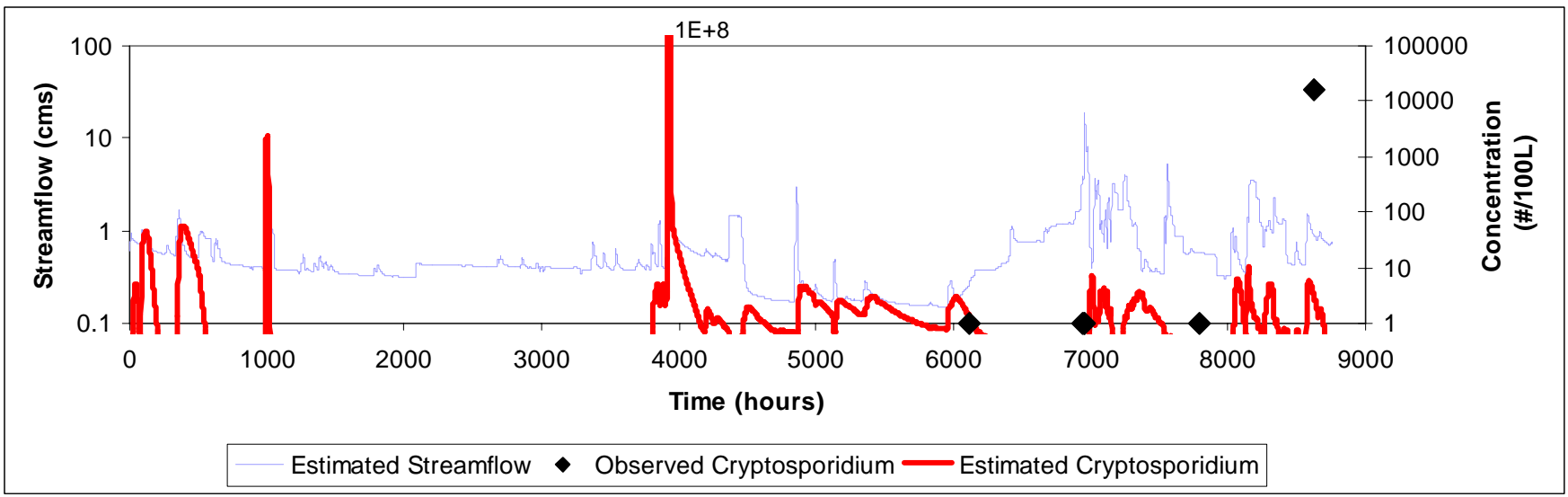

Figure S4. Cryptosporidium results for June 2002 to May 2003 below Elmira.

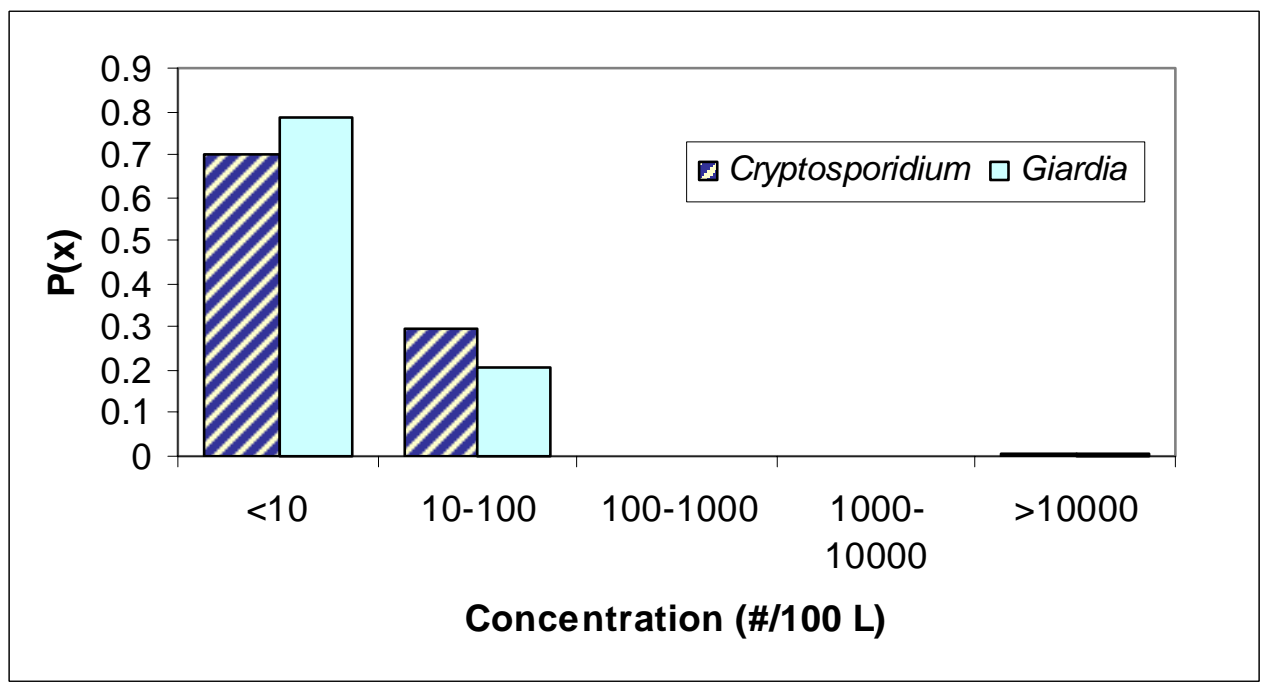

Figure S5. Normalized concentration frequency diagram based on simulated Cryptosporidium and Giardia results for June 2002 to May 2003 below Elmira.

Figure S5 presents a normalized frequency diagram of simulated Cryptosporidium and Giardia occurrence. Any true stream concentration that is below 10 per $100 \mathrm{~L}$ would not likely be detected 
using current methods for the detection and enumeration of the protozoa because of poor recovery efficiencies, and the need to sample large volumes of water.

\section{LITERATURE CITED}

Banning, N.; Toze, S.; Mee, B.J. Escherichia coli survival in groundwater and effluent measured using a combination of propidium iodide and the green fluorescent protein. J. Appl. Microbiol. 2002, 93, 69-76.

Chynoweth, R.W.; Hudson, J.A.; Thom, K. Aerobic growth and survival of Campylobacter jejuni in food and stream water. Lett. Appl. Microbiol. 1998, 27, 341-344.

Fenlon, D.R.; Ogden, I.D.; Vinten, A.; Svoboda, I. The fate of Escherichia coli and E. coli O157 in cattle slurry after application to land. J. Appl. Microbiol. 2000, 88, 149S-156S.

Hartley, D.M. Simplified process model for water sediment yield from single storms. part 1 - model formulation. Transact. ASAE, 1987, 30 (3), 710-717.

Himathongkham, S.; Bahari, S.; Riemann, H.; Cliver, D. Survival of Escherichia coli O157:H7 and Salmonella typhimurium in cow manure and cow manure slurry. FEMS Microbiol. Lett. 1999, 178, 251-157.

Hutchison, M.L.; Walters, L.D.; Moore, A.; Crookes, K.M.; Avery, S.M. Effect of length of time before incorporation on survival of pathogenic bacteria in livestock wastes applied to agricultural soil Appl. Environ. Microbiol. 2004, 70, 5111-5118.

Jiang, X.; Morgan, J.; Doyle, M.P. Fate of Escherichia coli O157:H7 in manure-amended soil. Appl. Environ. Microbiol. 2002, 68, 2605-2609. 
Kato, S.; Jenkins, M.; Fogarty, E.; Bowman, D. Cryptosporidium parvum oocyst inactivation in field soil and its relation to soil characteristics: analyses using the Geographic Information Systems. Science of the Total Environment. 2004, 321:47-58.

Korhonen, L.K.; Martikainen, P.K. Comparison of the survival of C. jejuni and C. coli in culturable form in surface water. Can. J. Microbiol. 1991, 37, 530-533.

Kudva, I.T.; Blanch, K.; Hovde, C.J. Analysis of Escherichia coli O157:H7 survival in ovine and bovine manure and manure slurry. Appl. Environ. Microbiol. 1998, 64, 3166-3174.

Nasser, A.M.; Huberman, Z.; Zilberman, A.; Greenfeld, S. Die-off and retardation of Cryptosporidium spp. oocysts in loamy saturated soil with secondary effluent. Water Sci. Technol. Water Supply. 2003a, 3(4), 253-259.

Nasser, A.M.; Zaruk, N.; Netzan, Y. Comparative survival of Cryptosporidium, Coxsackievirus A9 and Escherichia coli in stream, brackish and sea waters. Water Sci. Technol. 2003b, 47(3), 91-96.

Olson, M.E.; Goh, J.; Phillips, M.; Guselle, N.; McAllister, T.A. Giardia cyst and Cryptosporidium oocyst survival in water, soil and cattle feces. J. Environ. Qual. 1999, 28, 1991-1996.

Perrot, F.; Jouenne, T.; Feuilloley, M.; Vaudry, H.; Junter, G.-A. Gel immobilization improves survival of Escherichia coli under temperature stress in nutrient-poor natural water. Water Res. 1998, $32,3521-3526$.

Pokorny, N.J.; Weir, S.C.; Carreno, R.A.; Trevors, J.T.; Lee, H. Influence of temperature on Cryptosporidium parvum oocyst infectivity in river water samples as detected by tissue culture assay. $J$. Parasitol. 2002, 88(3), 641-643.

Robertson, L.J.; Campbell, A.T.; Smith, H.V. Survival of Cryptosporidium parvum oocysts under various environmental pressures. Appl. Environ. Microbiol. 1992, 58, 3494-3500. 
Sattar, S.A.; Chauret, C.; Springthorpe, V.S.; Battigelli, D.; Abbaszadegan, M.; LeChevallier, M. Giardia Cyst and Cryptosporidium Oocyst Survival in Watersheds and Factors Affecting Inactivation. AWWA Research Foundation and American Water Works Association. 1999.

Sinton, L.W.; Hall, C. H.; Lynch, P.A.; Davies-Colley, R.J. Sunlight inactivation of fecal indicator bacteria and bacteriophages from waste stabilization pond effluent in fresh and saline waters. Appl. Environ. Microbiol. 2002, 68, 1122-1131.

Terzieva, S.I.; McFeters, A. Survival and injury of E. coli, Campylobacter jejuni, and Yersinia enterocolitica in stream water. Can. J. Microbiol. 1991, 37, 785-790.

Thomas, C.; Hill, D.J.; Mabey, M. Evaluation of the effect of temperature and nutrients on the survival of Campylobacter spp. in water microcosms. J. Appl. Microbiol. 1999, 86, 1024-1032.

Wang, G.; Zhao, T.; Doyle, M.P. Fate of enterohemorrhagic Escherichia coli O157:H7 in bovine feces. Appl. Environ. Microbiol. 1996, 62, 2567-2570. 